\title{
Binding of the CBP2 protein to a yeast mitochondrial group I intron requires the catalytic core of the RNA
}

\author{
Alexandra Gampel and Thomas R. Cech ${ }^{1}$ \\ Howard Hughes Medical Institute, Department of Chemistry and Biochemistry, University of Colorado, \\ Boulder, Colorado 80309-0215 USA
}

The yeast CBP2 gene product is required for the splicing of the terminal intron (bI5) of the mitochondrial cytochrome $b$ pre-mRNA in vivo. In vitro, bI5 RNA self-splices efficiently only at high $\mathbf{M g C l}_{\mathbf{2}}$ concentrations ( $50 \mathrm{mM}$ ); at $5 \mathrm{mM} \mathrm{MgCl}_{2}$, efficient splicing requires purified CBP2 protein. To determine the sequences within bI5 recognized by the protein, we have constructed deletion and substitution mutants of the RNA. Their binding to CBP2 was assessed by their ability to inhibit protein-dependent splicing of the wild-type bI5 RNA. Several regions, including the large $\mathrm{L} 1$ and $\mathrm{L} 8$ loops, can be deleted without affecting binding. They can therefore be eliminated from consideration as critical recognition elements. In contrast, other changes prevent the RNA from binding CBP2 and also impair self-splicing. Thus, either the catalytic core contacts the protein directly, or the integrity of the core is required for proper display of other RNA sequences that bind the protein. The results are consistent with a model in which the CBP2 protein facilitates splicing by binding to and stabilizing the active structure of the RNA. However, a more specific model is proposed in which the protein specifically enhances $\mathbf{M g}^{\mathbf{2}}$ binding required for catalysis.

[Key Words: Yeast; CBP2 gene product; splicing; mitochondrial intron; RNA catalysis]

Received May 17, 1991; revised version accepted July 19, 1991.

Many group I introns have been shown to undergo selfsplicing in vitro (Cech 1990). Nevertheless, there are clear examples where splicing of these introns in vivo requires or is facilitated further by proteins. Several mitochondrial introns have open reading frames encoding maturases required for splicing of the intron containing their own mRNA (Lazowska et al. 1989; Perlman and Butow 1989|. Proteins encoded in the nucleus are also required for splicing of some fungal mitochondrial introns. Two of these, the CBP2 protein of Saccharomyces cerevisiae (McGraw and Tzagoloff 1983) and the mitochondrial tyrosyl-tRNA synthetase (cyt-18 protein) of Neurospora crassa (Akins and Lambowitz 1987) must interact directly with the unspliced precursor RNA, because the purified proteins function to allow or enhance splicing in vitro (Gampel et al. 1989; Majumder et al. 1989).

Because self-splicing and CBP2 protein-dependent splicing are blocked by the same mutations within the intron and progress through the same guanosine-dependent pathway, it does not seem likely that this protein could be a splicing enzyme in the traditional sense (Gampel et al. 1989). Rather, it has been proposed that CBP2 and perhaps other group I intron splicing factors are superimposing an additional level of catalysis on an

\footnotetext{
${ }^{1}$ Corresponding author.
}

intrinsically RNA-catalyzed process. To catalyze splicing, group I intron RNA must be folded into a highly ordered structure. Of central importance to this structure is the catalytic core region comprised of highly conserved sequences that have been demonstrated, in many cases, to be critical to splicing (Cech 1990; Couture et al. 1990). In a popular model, proteins bind to and stabilize the catalytically active conformation of the RNA, promoting correct folding of the core (Gampel et al. 1989; Cech 1990; Guo et al. 1991). However, exactly what these proteins recognize in the RNA and how they facilitate splicing remain largely unknown.

The terminal intron of the $S$. cerevisiae cytochrome $b$ gene (bI5) contains the sequences and structures characteristic of group IA introns (Davies et al. 1982; Michel et al. 1982). Its splicing factor is encoded by the nuclear gene $C B P 2$. cbp2 mutants are respiratory deficient due to a specific defect in excision of bI5 and thereby accumulate an unspliced cytochrome $b$ pre-mRNA (McGraw and Tzagoloff 1983; Hill et al. 1985). The splicing of other mitochondrial pre-mRNAs is unaffected by the $c b p 2$ mutation, suggesting that bI5 is the only intron that requires this particular splicing factor. Studies of the function of the CBP2 gene product have used the protein purified from wild-type $S$. cerevisiae mitochondria to promote splicing of bI5 in vitro. The bI5 intron is able to self-splice in vitro, although the reaction displays a 
strong dependence on $\mathrm{Mg}^{2+}$ ion concentration with a maximum rate at $50-100 \mathrm{~mm} \mathrm{Mg}{ }^{2+}$ (Gampel and Tzagoloff 1987; Partono and Lewin 1988). Addition of purified CBP2 protein to splicing reactions at $5 \mathrm{mM} \mathrm{Mg}{ }^{2+}$ greatly enhances the splicing rate over that in the absence of the protein (Gampel et al. 1989).

To uncover possible mechanisms of protein facilitation, we have begun to characterize the interaction between b15 and the CBP2 protein. Attempts to directly map contact points on the RNA by protein-dependent protection of the RNA from nuclease degradation have been unsuccessful. This may be caused by a short halflife of the RNA-protein complex not allowing for sufficient trapping of the complex under the conditions of nuclease treatment. It may be necessary to perform assay binding directly with saturating concentrations of protein. This will be technically feasible only when the protein can be purified in larger quantities in a soluble form.

As a substitute for direct mapping, we have made sitedirected mutations within bI5 and measured the effects of these changes on protein binding and on RNA catalysis. The binding assay uses the variant RNAs as competitive inhibitors of protein-dependent splicing of wildtype RNA. Variants that bind the protein as tightly as wild-type bI5 show that the deleted or mutated regions do not make substantial contributions to binding. Variants defective in protein binding could be of two subtypes. Where self-splicing activity of the variant RNA is also affected, it might be concluded that the altered sequences contribute directly to both the catalytically active structure and the protein-binding site. However, the diminution of protein binding could be an indirect effect of denaturation of the RNA structure. The most informative subclass with respect to protein recognition would include mutant RNAs that retain self-splicing activity but are no longer bound by the protein. In this case, the altered sequences would be good candidates for regions involved directly in the formation of the proteinbinding site. If the protein binds to the catalytic core, such a phenotype may not exist.

The results of the mutagenesis experiments reported in this paper indicate that there is significant overlap in sequences contributing to the active RNA structure and to the formation of the protein-binding site. This leads to a model of protein binding that invokes recognition of a structure or structures formed only in the context of the intact group I intron core.

\section{Results}

\section{Secondary structure}

Our approach to defining the protein-binding site on bI5 RNA involved the generation of bI5 variants with deletions or substitutions. Such variants are best designed with consideration of RNA structure. The secondary structure of bI5 was predicted with reference to the model for group I introns determined on the basis of phylogenetic arguments (Davies et al. 1982; Michel et al. 1982) and largely substantiated by studies of the Tet- rahymena rRNA intron (Cech 1990). For bI5, the predicted structure was verified in part by chemical modification with 1-cyclohexyl-3-(2-morpholinoethyl)-carbodiimide metho-p-toluene sulfonate (CMCT). This reagent modifies N3 of uridines and, to a lesser extent, N1 of guanosines with specificity for unpaired bases (Moazed et al. 1986; Ehresmann et al. 1987). Sites of modification were revealed by reverse transcription from oligonucleotide primers.

Comparison of modification under native and denaturing conditions indicates which residues are involved in base-pairing in the native state. The gel shown in Figure 1 is an example of how the secondary structure assignments were made from the CMCT modification data. The uridines of L6b (nucleotides 394, 396, 399, 402, and 405) are modified heavily under native conditions compared with their neighbors and are therefore designated as unpaired. U340 in J5/4, as well as U328 and U324 in L5, are modified heavily, indicating that they are also unpaired in the native state. The uridines of $\mathrm{P} 6 \mathrm{~b}\left[5^{\prime}\right]$ ( $\mathrm{nu}-$ cleotides 371-378) and $\mathrm{P} 6 \mathrm{~b}\left[3^{\prime}\right]$ (nucleotides $411-424$ ) are modified only slightly under native conditions, indicat-

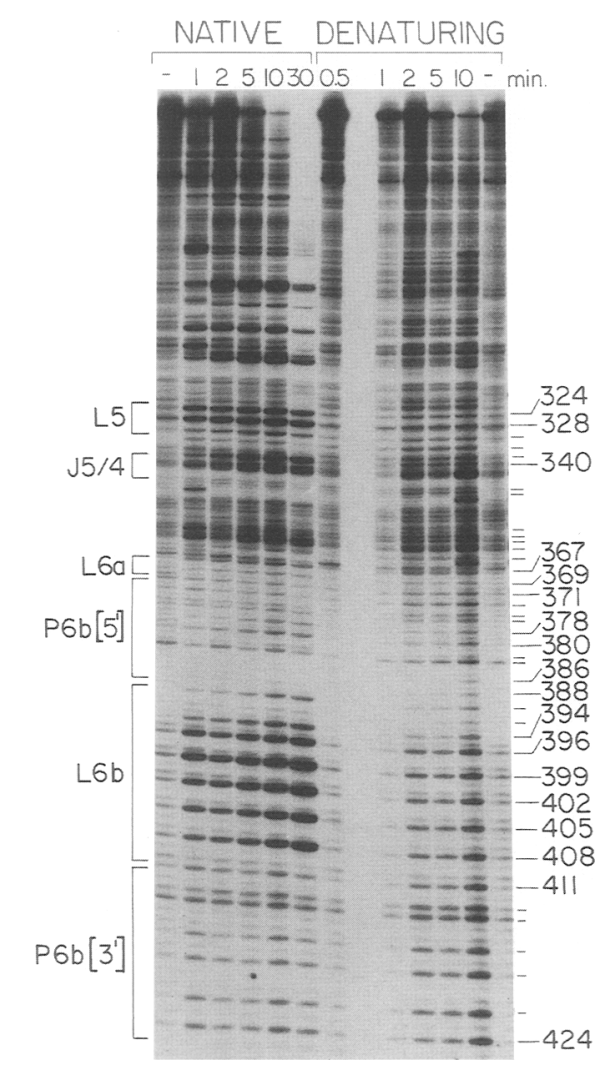

Figure 1. CMCT modification of bI5 RNA. High-resolution polyacrylamide gel of CMCT-modified wild-type bI5 RNA with sites of modification revealed by reverse transcription from the internal primer IP437-20. Reactions were done under native $\left(37^{\circ} \mathrm{C}\right.$ plus $\left.\mathrm{Mg}^{2+}\right)$ and denaturing $\left(95^{\circ} \mathrm{C}\right.$ minus $\left.\mathrm{Mg}^{2+}\right)$ conditions. Modification of unpaired residues is exemplified by the uridines in L $6 \mathrm{~b}$ and paired residues by the uridines in $\mathrm{P} 6 \mathrm{~b}\left[5^{\prime}\right]$. The duration of reactions is indicated in minutes. CMCT was not added to the reaction in the - lane. 
ing that these regions are paired as predicted. Unexpectedly, the two uridines in L6a are undermodified under native conditions, suggesting that they may also be paired. The proposed tertiary interaction (P11) between L7.1 and L6a (Michel and Westhof 1990) could account for the undermodification in L6a.

A compilation of results, including studies with different oligonucleotide primers, is provided in Figure 2A. The data indicate that the predicted structure is essentially correct and the same at 5 and $50 \mathrm{~mm} \mathrm{Mg}{ }^{2+}$ /data not shown). The conserved helical structures $\mathrm{P} 2-\mathrm{P} 5$ are clearly base-paired, whereas the uridines in $\mathrm{J} 2 / 3, \mathrm{~J} 3 / 4$, $\mathrm{J4} / 5, \mathrm{~L} 5, \mathrm{J5} / 4$, L6b, and J6/7 are unpaired and accessible to modification. Very little guanosine modification was observed under the conditions used. Consequently, it is difficult to interpret the finding that light modification is seen for the single uridine in the $3^{\prime}$ strand of $\mathrm{P6}$, as there is no information about the paired state of the rest of the helix.

The accessibility of $\mathrm{P} 7$ nucleotides to the CMCT reagent is consistent with earlier results of chemical modification with the Tetrahymena rRNA intron (Inoue and Cech 1985; Jaeger et al. 1990). The importance of P7 base-pairing to catalytic activity has been demonstrated unequivocally by phylogenetic comparison (Cech 1988) and compensatory mutations (Burke et al. 1986). Thus, the accessibility to modification can be interpreted as reflecting a dynamic equilibrium between paired and unpaired states of $\mathrm{P} 7$. It is even possible that the $\mathrm{P} 7$ residues are most often unpaired, with the helix forming only transiently at a critical step in the reaction.

The results of CMCT modification confirm the basepairing predicted by Michel and Westhof (1990) for the P7.1-P7.1a region in group IAl introns. This subgroup includes 16 introns, all of which potentially form very similar structures in this joining region between P3 and $\mathrm{P7}$. The introns from bacteriophage $\mathrm{T} 4$ are included in the group IA2 subgroup and have a distinctly different predicted secondary structure in this region (Shub et al. 1988).

\section{CBP2 binding of bI5 variants}

The bI5 secondary structure model was used to design variant RNAs for studies to localize the protein-binding site. Each variant was tested for splicing activity and for its ability to act as an inhibitor of the protein-dependent splicing reaction. $K_{\mathrm{i}}$ values were determined under con- ditions where both the RNA and the protein concentrations were below the value of $K_{\mathrm{m}}$. The determinations were done by two methods, which are described in the legend to Figure 3 and in Materials and methods. Results from the two methods were in close agreement.

The bI5 variant $\Delta$ L1-B has entirely wild-type sequences but is missing the $5^{\prime}$ exon and the 223 nucleotides between the $5^{\prime}$-splice site and the $5^{\prime}$ terminus of the $5^{\prime}$-exon-binding site (Fig. 2B). The $K_{\mathrm{i}}$ for $\Delta \mathrm{L}$ 1-B was determined by method $\mathrm{A}$ to be $14 \mathrm{~nm}$ (Fig. 3) and by method B to be 2-8 nM (Table 1). These numbers are equal within experimental error to each other and to the $K_{\mathrm{i}}$ value determined for the full-length bI5 RNA. We therefore interpret $\Delta \mathrm{L} 1-\mathrm{B}$ binding as representative of wild-type bI5 binding.

The large loops, Ll (221 nucleotides) and L8 (152 nucleotides|, are unusual features of the bI5 intron because of their size and richness in adenosines and uridines (94\% for $\mathrm{L1} ; 79 \%$ for L8). Deletion of either of these loops ( $\Delta \mathrm{L} 1-10$ and $\Delta \mathrm{L} 8$ variants) does not affect binding (Table 1). In contrast, deletion of the P6a, P6b, and L6b region $(\Delta \mathrm{L} 6), \mathrm{P} 7.1-\mathrm{P7}$.1a $(\Delta \mathrm{P} 7.1)$, or sequences $3^{\prime}$ to $\mathrm{P} 8\left[5^{\prime}\right]$ $(\Delta \mathrm{L} 8 / B g / I I)$, results in drastic disruption of binding to CBP2 (>200 nM reflecting no detectable inhibition). All of these deletion variants are defective in self-splicing as well as protein-dependent splicing. CMCT modification of these variant RNAs gave patterns of modification indistinguishable from the wild-type pattern outside the secondary structure elements directly affected by the given deletion (data not shown). Thus, the secondary structure is still formed in the context of the deletion mutants.

The specificity of recognition was tested by adding other group I introns to the protein-dependent splicing reaction. The group IA introns from bacteriophage T4 ( $n r d B$ and $t d$; Shub et al. 1988) and the group IB intron from the Tetrahymena rRNA (L-21 ScaI ribozyme; Zaug et al. 1988/ did not inhibit the reaction detectably at concentrations up to $200 \mathrm{~nm}$.

In the mutant designated RP5td, the $\mathrm{J4} / 5, \mathrm{P} 5, \mathrm{~L} 5$, and J5/4 regions of bI5 were replaced with the same regions from the $t d$ intron (Fig. 4A). This mutant RNA selfsplices, although it has an increased requirement for $\mathrm{Mg}^{2+}$. Splicing rates for RP5td approach that for the wild-type RNA as the concentration of $\mathrm{Mg}^{2+}$ is increased to $200 \mathrm{mM}$ (Fig. 4B). In the presence of the protein at $5 \mathrm{~mm} \mathrm{Mg}{ }^{2+}$, splicing of this RNA is barely detectable $\mid<10 \%$ wild type; data not shown). However, the RP5td

Figure 2. Secondary structure of bI5 RNA. The structure is drawn according to the convention for group I introns with conserved stem-loop structures P1-P9 and L1-L9 (Burke et al. 1987). (A) Compilation of CMCT modification results with primers in addition to the one shown in Fig. 1. Circles indicate residues preferentially modified under native conditions [heavy lines indicate 2- to 5 -fold higher modification than average, e.g., nucleotide 396-408 (heavy) vs. nucleotide 394 (light)]; open boxes indicate undermodified uridines (e.g., 386 and 388); shaded boxes indicate residues modified under denaturing conditions and undermodified under native conditions (e.g., nucleotides 367-380). Modification was not determined for P1[5'], L1, L8, P8, P9, P9.1, and the $3^{\prime}$ end of the intron. (B) Sequences deleted or altered by mutagenesis. $\Delta \mathrm{L} 1-\mathrm{B}$ is missing all sequences preceding the $5^{\prime}$ exon-binding site. In $\Delta \mathrm{L} 6$, the indicated region is deleted and replaced with a SmaI site, $5^{\prime}$-CCCGGG-3'. $\Delta$ P7.1 is a complete deletion of all sequences between P7 and P3. In $\Delta \mathbf{L} 8$, the 152-nucleotide wild-type $\mathrm{L} 8$ is replaced with a $B g$ III site, $5^{\prime}$-AGAUCU-3'. The $\Delta \mathrm{L} 8 / B g / I I$ variant is a runoff transcript from the $\Delta \mathrm{L} 8$ template linearized at the BgIII site inserted downstream of P8 (5'-AGATCT-3' in the DNA template). The G-site mutants are described in Fig. 5. 
(A)

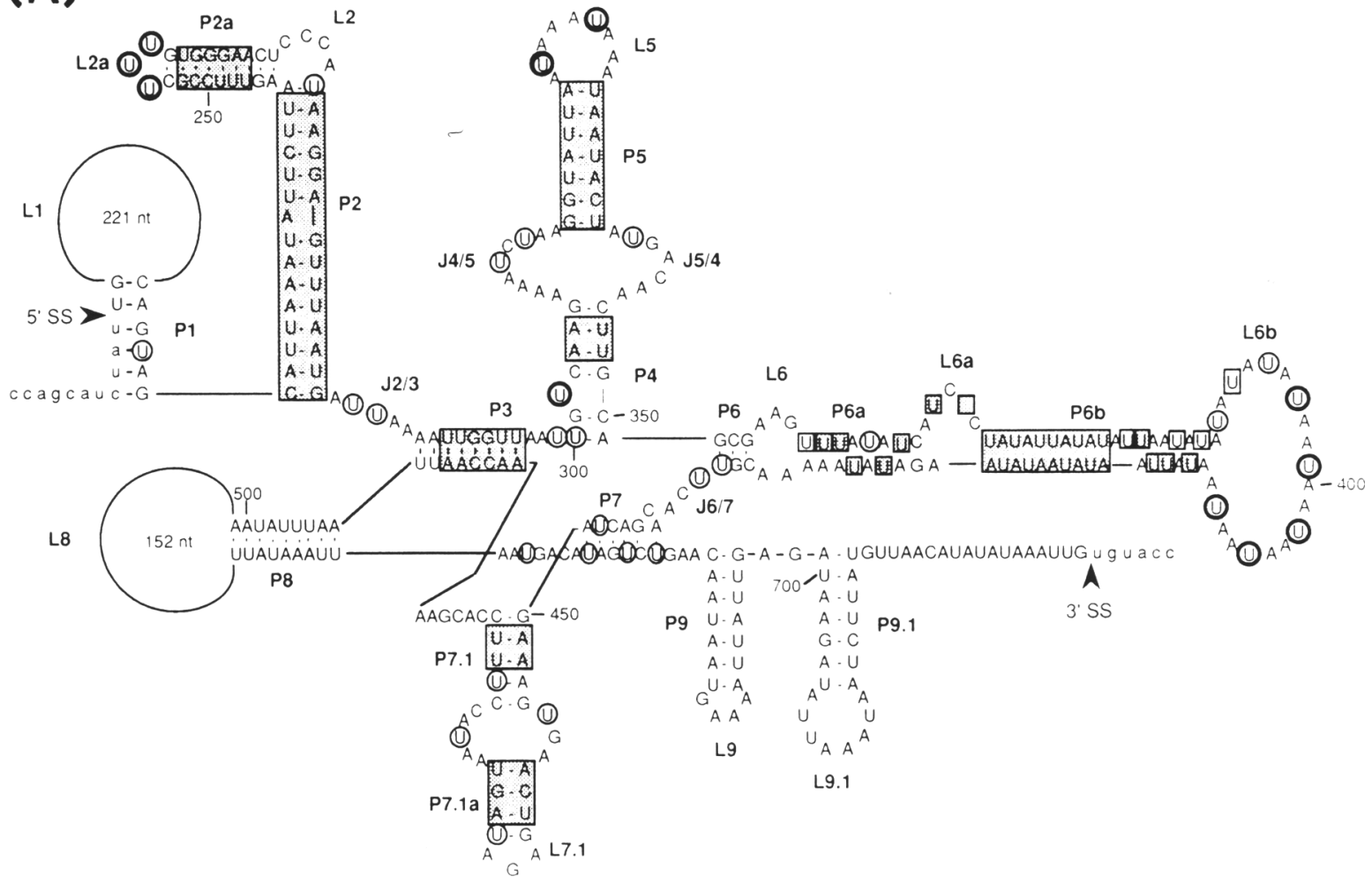

(B)

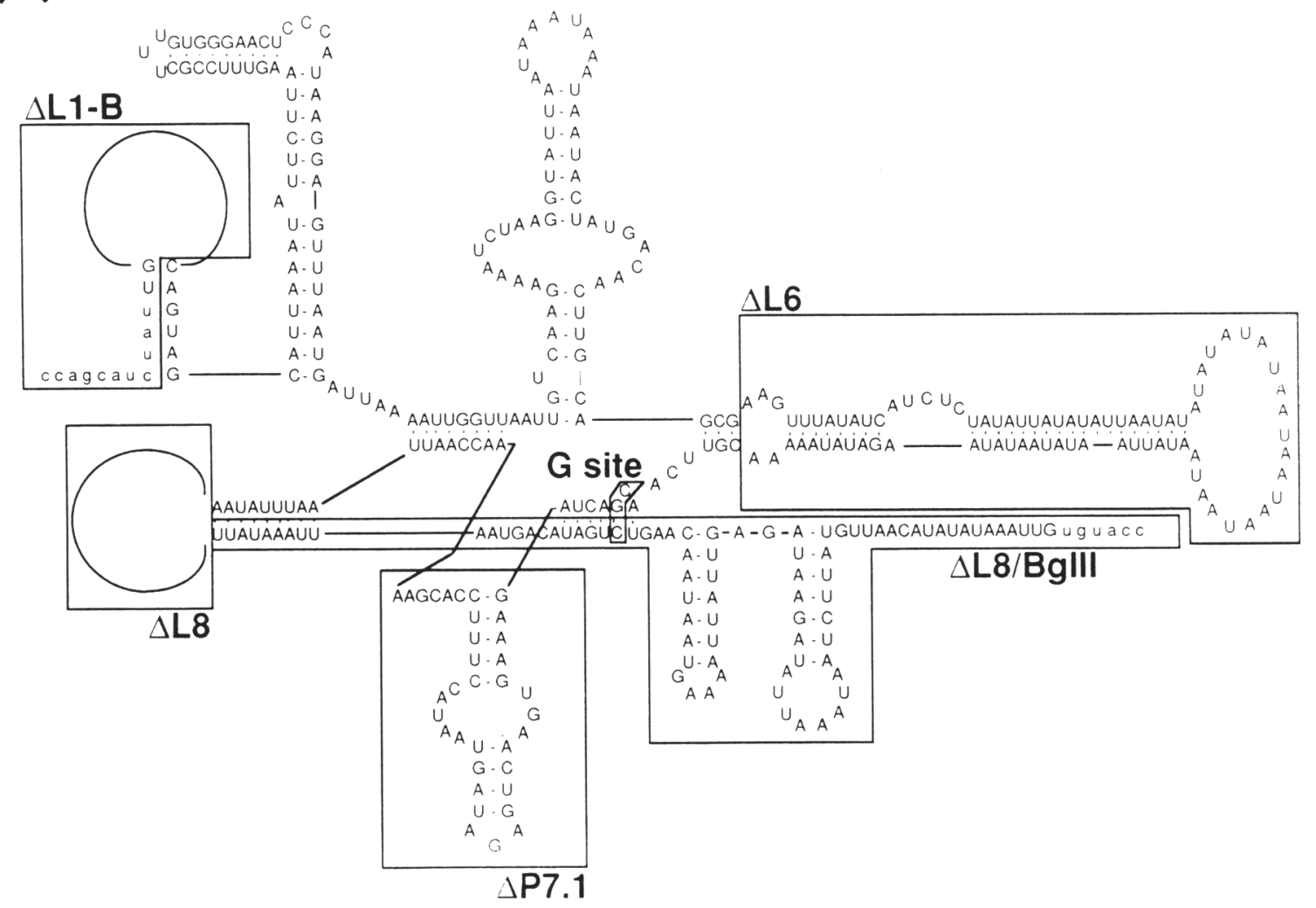

Figure 2. (See facing page for legend.) 
(A)

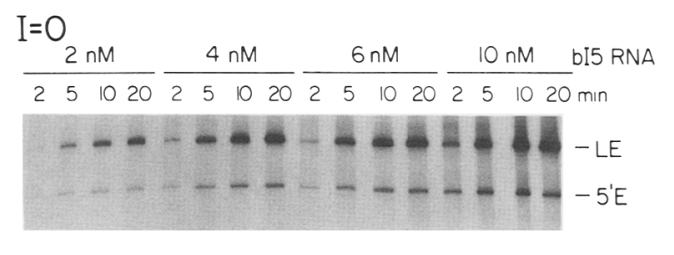

$\mathrm{I}=10 \mathrm{nM}$
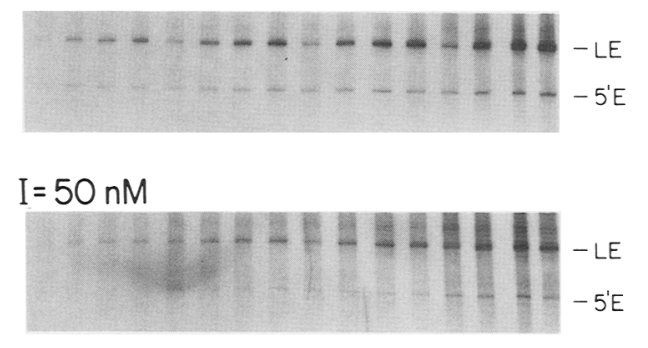

$\mathrm{I}=200 \mathrm{nM}$

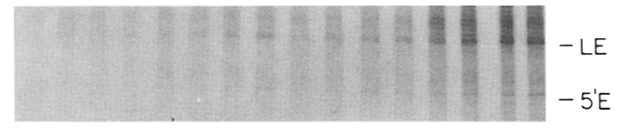

(B)

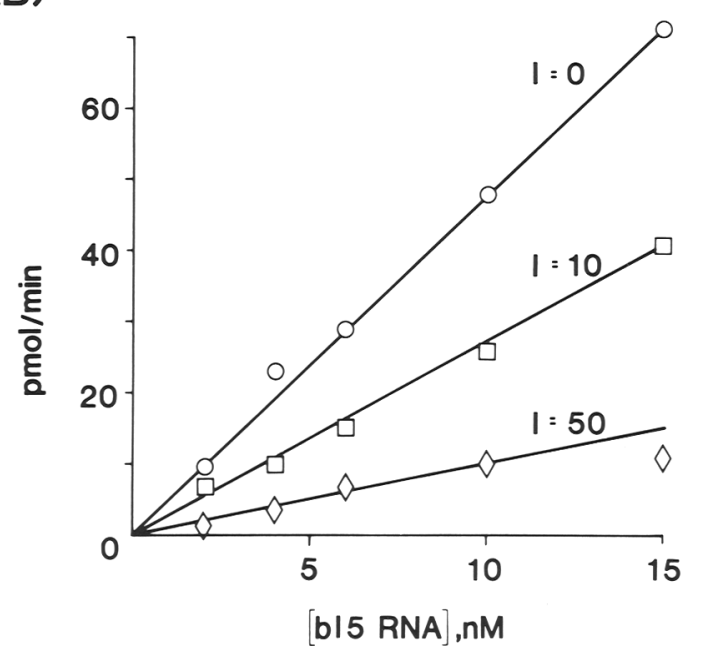

RNA binds well $\left(K_{\mathrm{i}}=30 \mathrm{nM}\right)$ to the CBP2 protein at 5 $\mathrm{mM} \mathrm{Mg}^{2+}$ (Table 1). A possible unified explanation for all of these effects is that the RP5td replacement has perturbed the RNA structure required for catalysis, leading to an increased $\mathrm{Mg}^{2+}$ requirement for both self-splicing and protein-facilitated splicing, but that the contribution of CBP2 to splicing is largely the same.

\section{G-site mutants}

To further assess the importance of the core of the group I intron structure in CBP2 protein recognition, point mutants within P7 were made. The single-nucleotide change, C263A (Tetrahymena numbering), replaces the $\mathrm{P} 7$ bulged $\mathrm{C}$ residue conserved among group IA introns to an $A$ as is found in group IB introns (Fig. 5A). This
Figure 3. Kinetic analysis. (A) Gels showing the kinetics of splicing product formation in the protein-dependent reaction as a function of precursor and inhibitor RNA concentrations. Because the unspliced precursor and excised IVS RNAs are not resolved on these $10 \%$ polyacrylamide gels, the upper portion of the gel containing these bands is not shown. Reactions were carried out at the indicated concentrations of uniformly labeled wild-type bI5 RNA in the presence of unlabeled $\triangle \mathrm{L} 1-\mathrm{B}$ RNA as inhibitor $(I)$ at the indicated concentrations. Aliquots were taken at 2,5,10, and 20 min of reaction. Products are the ligated exons and the 5' exon. Concentrations of RNA (as indicated) and protein (15 $\mathrm{nM}$ ) were very small relative to the approximate $K_{\mathrm{m}}$ value of $200 \mathrm{nM}$ estimated from determinations of reaction rate as a function of RNA concentration $>10 \mathrm{nM}$ (A. Gampel, unpubl.). (B) Graphic analysis of the initial rate of 5 '-splice site cleavage as a function of RNA concentration. Rates were determined from quantitative analysis of autoradiographs in $A$ (for calculations, see Materials and methods). The slope of the line gives a value of $\mathrm{V}_{\max } / K_{\mathrm{m}}$ in the absence of inhibitor and $\mathrm{V}_{\max } /$ $K_{\mathrm{m}}$ (app) in the presence of inhibitor. For competitive inhibition, $K_{\mathrm{m}}(\mathrm{app})=K_{\mathrm{m}}\left(1+[I] / K_{\mathrm{i}}\right)$ and the value of $K_{\mathrm{i}}$ can be calculated. From the data at $I=10 \mathrm{nM}$, the calculated $K_{\mathrm{i}}$ is $14 \mathrm{nM}$ and from $I=50 \mathrm{nM}$, the calculated $K_{\mathrm{i}}$ is $13 \mathrm{nM}$. The low extent of reaction at $I=200 \mathrm{nM}$ did not allow for the calculation of rates or $K_{\mathrm{i}}$ from these data.

replacement could affect the intron structure either by changing the identity of the bulged nucleotide or by producing six contiguous base pairs in $\mathrm{P} 7$ coupled to an extension of $\mathrm{j6/7}$. The splicing rate for this mutant RNA is less than that for the wild type (5- to 10-fold decreased at $0.2 \mathrm{~mm}$ GTP|, but both protein-dependent and selfsplicing reactions occur with $\mathrm{Mg}^{2+}$ dependence similar to that of the wild-type RNA (data not shown). Results of competition experiments show the $K_{\mathrm{i}}$ for the C263A RNA to be approximately equal to wild-type RNA (Table 1).

The mutation G264A alters the G of the G : C pair, a critical component of the guanosine-binding site /Michel et al. 1989). Unlike the change in the bulged nucleotide, the G264A mutation drastically affects protein binding. G264A mutant RNA does not inhibit the protein-dependent reaction even at concentrations up to $900 \mathrm{nM}$. This mutant is also completely defective in guanosine-dependent splicing at high $\mathrm{Mg}^{2+}$ levels or in the presence of the protein.

The results with the G264A mutant suggested that formation of the guanosine-binding site might be critical for $\mathrm{CBP} 2$ protein recognition. Further experiments were done to distinguish between a direct contact of the protein at the G site, dependent on the identity of the G : C pair, versus an indirect dependence of protein binding on the structural integrity of the G site. Two additional G-site mutations were made, changing C311 of the G : C pair to a $U$ in the wild-type background /generating a $\mathrm{G}$ : $U$ wobble pair at the $\mathrm{G}$ site) and in the G264A mutant background (generating an A : U base pair at the G site).

The set of variants with $\mathrm{G}: \mathrm{C}$ (wild type), A : C, G : U, or $A: U$ at the $G$ site were tested for splicing with guanosine $(G)$, 2-aminopurine ribonucleoside (2-AP), or 
Table 1. CBP2 binding and splicing activity of bI5 variants

\begin{tabular}{lcccc}
\hline & \multicolumn{2}{c}{$K_{\mathrm{I}}(\mathrm{nM})$} & & \\
\cline { 2 - 4 } Inhibitor & $\begin{array}{c}\text { method } \\
\text { A }\end{array}$ & $\begin{array}{c}\text { method } \\
\text { B }\end{array}$ & Binding $^{\text {a }}$ & $\begin{array}{c}\text { Self- } \\
\text { splicing } \\
\text { activity }\end{array}$ \\
\hline Wild-type bI5 & n.t. & $2-8$ & + & + \\
$\Delta$ L1-10 & n.t. & $2-8$ & + & + \\
$\Delta$ L1-B & 14 & $2-8$ & + & n.a. \\
$\Delta$ L8 & 10 & $2-8$ & + & + \\
$\Delta$ L6 & n.t. & $>200$ & - & - \\
$\Delta$ P7.1 & n.t. & $>200$ & - & - \\
$\Delta$ L8/BglII & n.t. & $>200$ & - & - \\
RP5td & 30 & n.t. & + & $1+1$ \\
C263A & $9-13$ & $2-8$ & + & $1+1$ \\
G264A & $>900$ & n.t. & - & - \\
T4 nrdB & n.t. & $>200$ & - & n.a. \\
T4 $t$ td & n.t. & $>200$ & - & n.a. \\
Tetrahymena & & & & \\
$\quad$ L-21/ScaI & n.t. & $>200$ & - & n.a. \\
\hline
\end{tabular}

(n.t.) Not tested; (n.a.) not applicable.

${ }^{a}$ Results of $K_{\mathrm{i}}$ determinations by methods A (see Fig. 3 ) and B (see Materials and methods) are summarized.

bSelf-splicing activity was determined as described in Materials and methods and is indicated as + (at least $80 \%$ of wild-type activity) or $-<10 \%$ of wild-type activity) except for RP5td (see Fig. 4) and C263A (10-20\% activity).

2-amino-6-chloropurine ribonucleoside (6-Cl-2-AP) as the cofactor for $5^{\prime}$-splice site cleavage. For the Tetrahymena ribozyme, the cofactor preference is determined by the identity of the base pair at the G site. The G : C or $G$ : $U$ pair prefers $G$ as a cofactor, whereas the $A: C$ or A : U pair prefers 2-AP (Michel et al. 1989) or 6-Cl-2-AP, the latter having a twofold lower $K_{\mathrm{m}}$ (M. Hanna, pers. comm.). For bl5, the A : U variant does not splice with G, but $5^{\prime}$-splice site cleavage proceeds efficiently with either of the other cofactors (Fig. $5 \mathrm{C}$ ). No exon ligation occurs with the A : U variant. This is expected; because the A : $U$ pair does not bind exogenous $G$, it is not expected to bind the $3^{\prime}$-terminal $G$ as would be necessary for exon ligation (Michel et al. 1989). Cleavage was not detected for the A : C variant with 2-AP or for the $G: U$ variant with $G$ under the conditions tested (data not shown). These results differ from those obtained with the Tetrahymena intron where the analogous variants retain splicing activity with appropriate cofactor preference.

In addition to self-splicing, the $\mathrm{A}: \mathrm{U}$ variant is able to undergo protein-dependent splicing with 2-AP or 6-Cl-2AP (Fig. 5C). This renewal of protein recognition as compared with the A : C mutant occurs as a result of the single-base change, C311U, which restores a base pair at the $\mathrm{G}$ site. This leads to the interpretation that the identity of the base pair at the G site is not important to CBP2 protein recognition, because bI5 RNAs with either $\mathrm{G}: \mathrm{C}$ or $\mathrm{A}: \mathrm{U}$ at the $\mathrm{G}$ site are able to undergo proteindependent splicing. However, the integrity of the cofactor-binding site must be critical because RNAs with a mismatch at the $\mathrm{G}$ site do not bind the CBP2 protein.

\section{Discussion}

We have investigated the binding specificity of the CBP2 protein for bI5 by mutational analysis of the RNA. Because the intron self-splices, it has been possible to characterize mutant RNAs with respect to the effect of the mutation on catalytic activity as well as protein binding. To a first approximation, the mutants fall into two categories. Some changes affect neither catalytic activity nor binding, whereas others drastically reduce both. The variants that retain wild-type binding and activity allow us to eliminate several sequences as direct contact points for the protein. Both of the large loops, $\mathrm{L} 1$ and $\mathrm{L} 8$, can be deleted from bI5 without disrupting protein binding, indicating that the combined 368 nucleotides comprising these loops do not contribute to formation of the binding site. Also, we were able to replace L4/5, P5, and L5 with the analogous regions from the $t d$ intron and generate a hybrid intron capable of binding the protein. Because the $t d$ sequences are very dissimilar to the bI5 sequences, we conclude that this region, above the P4 stem, is unlikely to contact the protein in a sequencespecific manner. Although a protein contact involving recognition of secondary structure with minimal sequence requirement cannot be ruled out, the sizes of the L4/5 internal loop and P5 stem are changed considerably by the $t d$ replacement. Finally, it appears that the identity of the bulged nucleotide in $\mathrm{P} 7$ and the identity of the base pair at the G-binding site are not important for protein recognition, as the C263A and G264A : C311U variants undergo protein-dependent splicing.

Many of the variants fell into the class of mutants that did not bind the protein and were also unable to selfsplice. This group included RNAs with deletions or mutations in P6, P7, and P7.1. One interpretation for these results is that these variants can be classified as denaturation mutants. Because the secondary structures of these RNAs are not altered from the wild type, as indicated by reactivity of uridines with CMCT, denaturation implies a loss of tertiary structure or unfolding of the RNA. The loss of the catalytic core structure would account for the self-splicing defect. By extension, the defect in binding would indicate that formation of the protein-binding site occurs only in the context of the correctly folded intron. A similar situation exists for the interaction between yeast tRNA ${ }^{\text {Phe }}$ and phenylalanyl tRNA synthetase. Although the synthetase does not specifically contact any of the nucleotides involved in tertiary interactions, the integrity of those interactions is required for protein recognition as well as for tertiary structure formation (Sampson et al. 1990).

The activities of the G-site variants $\mathrm{A}: \mathrm{C}$ and $\mathrm{A}: \mathrm{U}$ lend further support to the argument that the core structure of the RNA is required for formation of the proteinbinding site. The $\mathrm{A}$ : $\mathrm{C}$ variant is completely deficient in self- and protein-dependent splicing and does not bind the protein. The compensatory mutation that restores base-pairing, concomitant with a change in base-pair identity to A : U, permits both self- and protein-dependent splicing provided that the cofactor is $2-\mathrm{AP}$ or $6-\mathrm{Cl}-$ 


\section{(A)}

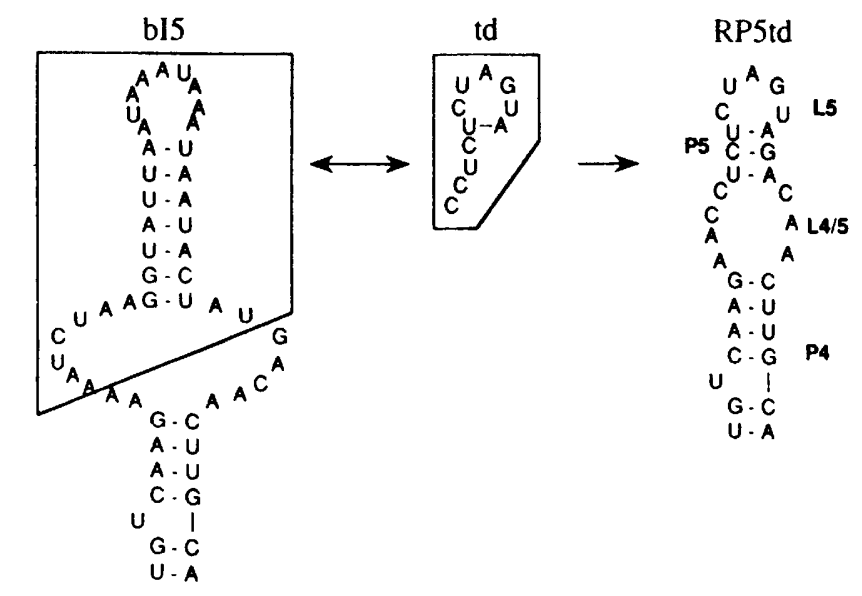

(B)
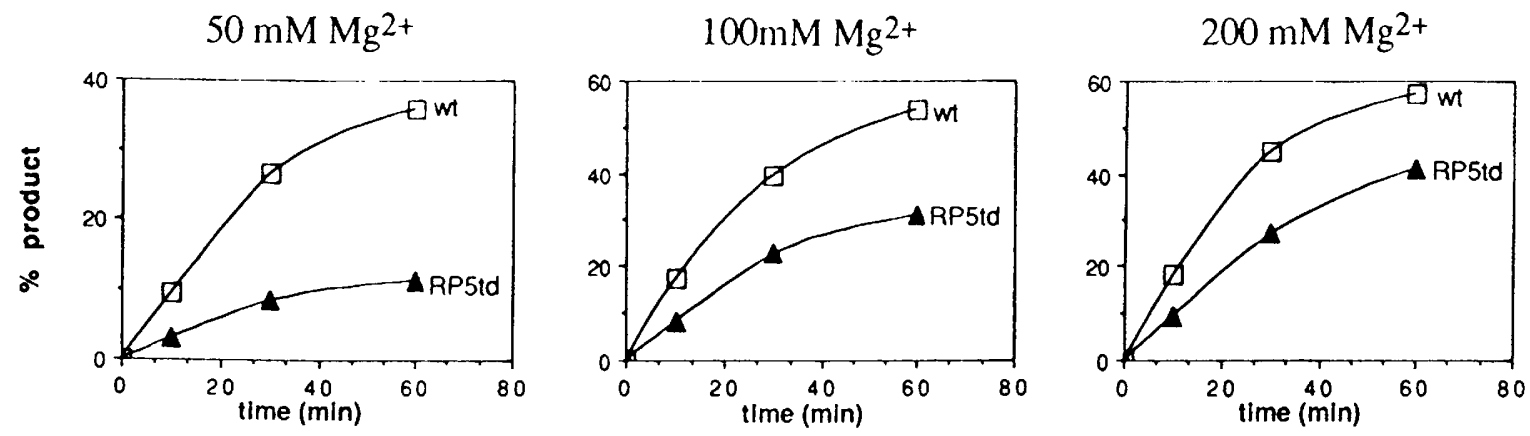

Figure 4. Replacement mutant RP5td. $(A)$ In the RP5td variant, nucleotides 309-340 from bI5 were replaced with 11 nucleotides from the L4/5-P5-L5 region of the $t d$ intron. (B) Kinetics of self-splicing for the RP5td variant compared to the wild type. Assays at 50, 100, and $200 \mathrm{mM} \mathrm{Mg}^{2+}$ were as described in Materials and methods. Quantitation of precursor, linear IVS, and ligated exon product bands were used to determine percent product formed as [(counts in IVS + counts in ligated exons $] \times 100] /$ total counts.

2-AP. Thus, the altered identity of the nucleotide (G264A) in the A : C variant cannot account for the defect in protein binding. Instead, it appears that CBP2 protein binding is sensitive to the base-paired state at the G site.

Having a base pair at the $G$ site might be required for protein binding in one of two ways. First, the $G$ site might be a nucleating element for the active structure so that the entire core is unable to form without prior formation of the $G$ site. This leaves open a wide range of possibilities for the exact location of the protein-binding site, excluding only $\mathrm{L} 1, \mathrm{~L} 8$, the $\mathrm{P} 7$ bulge, and the region above P4. A second possibility is that the base pair at the $G$ site only affects the local structure of the inner core. In effect, then, the overall tertiary structure forms, but the local geometry of P7 and the G site is altered with respect to other core internal sequences and structures. This leads to a model whereby the protein binds to the active core, perhaps even entering the catalytic pocket. The possible sequences contributing directly to the pro- tein-binding site according to this model would be limited to those in close contact with and structurally dependent on the G site. Further experiments will be required to distinguish between these two interpretations.

In addition to localizing the protein-binding site, we would like to understand the mechanism by which the protein facilitates splicing of a specific group I intron. The commonly invoked working hypothesis for this and other systems is that the protein binds to the RNA and stabilizes a catalytically active conformation. Implicit in this hypothesis is the assumption that the predominant structure present under physiological conditions is inactive for splicing. The AU-rich nature of bI5, combined with several large and potentially unstructured nonconserved sequences, might have been expected to make the active conformation less favored at low $\mathrm{Mg}^{2+}$. However, we could not distinguish the secondary structure formed under conditions where the intron does and does not self-splice. Thus, unless there is some subtle secondary structure defect at low $\mathrm{Mg}^{2+}$ levels that is corrected or 
(A)

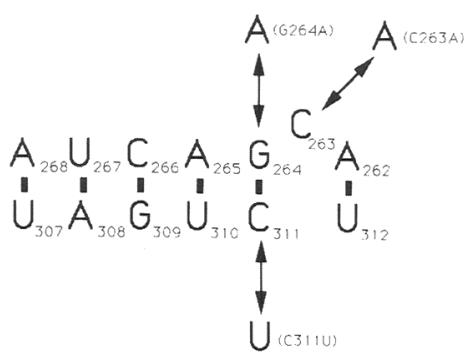

(B)

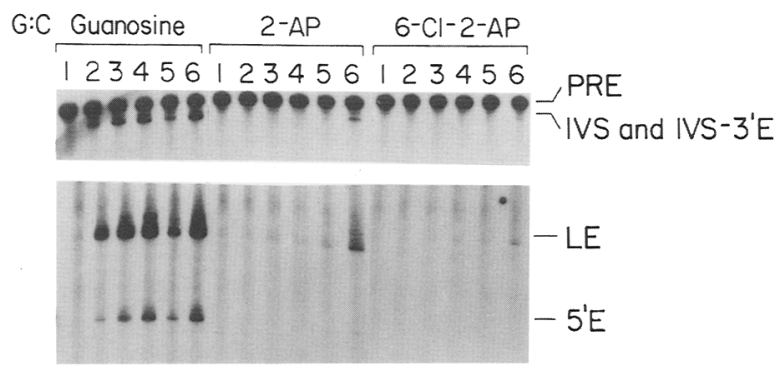

(C)
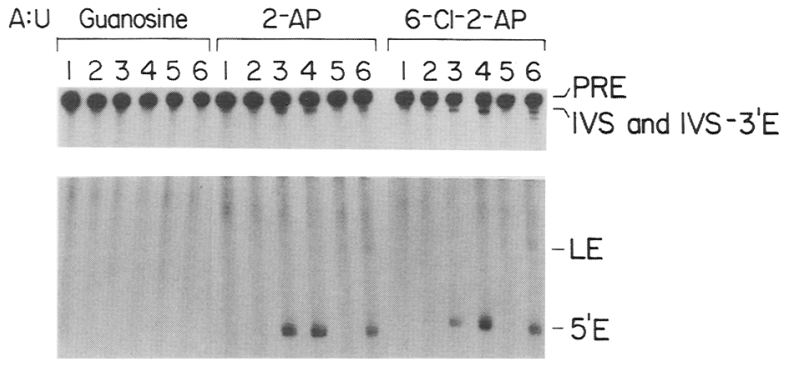

(D)

\begin{tabular}{|ccccccccc|}
\hline & \multicolumn{3}{c}{ - Protein } & & \multicolumn{3}{c|}{ + Protein } \\
\cline { 2 - 4 } \cline { 6 - 8 } G site & $\underline{\mathrm{G}}$ & $\underline{2-\mathrm{AP}}$ & $\underline{6-\mathrm{Cl}-2-\mathrm{AP}}$ & & $\underline{\mathrm{G}}$ & $\underline{2-\mathrm{AP}}$ & $\underline{6-C l-2-\mathrm{AP}}$ \\
G:C & $100 \%$ & 0 & $3 \%$ & & $100 \%$ & $15 \%$ & $5 \%$ \\
A:C & 0 & 0 & N.T. & & 0 & 0 & N.T. \\
A:U & 0 & 18 & $33 \%$ & & 0 & $9 \%$ & $13 \%$ \\
G:U & 0 & 0 & N.T. & & 0 & 0 & N.T. \\
\hline
\end{tabular}

Figure 5. G-site mutants. $(A)$ Preparation of the mutants G264A (A : C), G264A: C311U (A:U), C311U (G:U), and C263A (bulged nucleotide) is described in Materials and methods. The numbering system used for P7 in the diagram is that for the Tetrahymena rRNA intron (Burke et al. 1987). (B) Uniformly labeled bI5 RNA was reacted with G, 2-AP, or 6-Cl-2-AP for $30 \mathrm{~min}$ at $5 \mathrm{mM} \mathrm{Mg}^{2+}$ (lane 1), $20 \mathrm{mM} \mathrm{Mg}^{2+}$ (lane 2), $50 \mathrm{mM}$ $\mathrm{Mg}^{2+}$ (lane 3), $100 \mathrm{mM} \mathrm{Mg}{ }^{2+}$ (lane 4), $5 \mathrm{mM} \mathrm{Mg}^{2+}$ plus protein (lane 5), and $20 \mathrm{~mm} \mathrm{Mg}^{2+}$ plus protein (lane 6). (Top) Precursor, IVS, and $5^{\prime}$ exon-IVS in a 2 -hr exposure of the dried gel. (Bottom) The ligated exon and 5 -exon product in a 16-hr exposure of the same gel. $(C)$ Reactions as in $B$ except the A : $\mathrm{U}$ variant RNA was used. $(D)$ Quantitation of the reactions shown in $B$ and $C$ and data from gels not shown for the A:C and G:U variants. Splicing is given as a percentage of the wild-type reaction with guanosine.

compensated by CBP2 binding, the proposed structural stabilization must be at the level of tertiary structure.
This will be tested in the future with probes more revealing of tertiary structure, such as free radicals generated by $\mathrm{Fe}(\mathrm{II})-\mathrm{EDTA}$.

Here, we propose a new model whereby the defect in bI5 relative to other self-splicing introns resides at a specific $\mathrm{Mg}^{2+}$-binding site. The $\mathrm{Mg}^{2+}$ profile of the selfsplicing and protein-dependent splicing reactions (Gampel et al. 1989) is consistent with $\mathrm{Mg}^{2+}$ having a saturable binding site. According to this model, the high $\mathrm{Mg}^{2+}$ requirement in self-splicing reflects a low affinity for that ion at a specific site that must be filled for splicing to occur, perhaps because the metal ion participates directly in active site chemistry. The function of the protein would be to strengthen, directly or indirectly, the $\mathrm{Mg}^{2+}$ site. One possible type of direct interaction is the donation of a ligand for $\mathrm{Mg}^{2+}$ by an amino acid side chain of CBP2. That is, the correctly folded bI5 RNA might lack a ligand required for tight binding of $\mathrm{Mg}^{2+}$, which is provided by RNA functional groups in the Tetrahymena intron and others that self-splice at low $\mathrm{Mg}^{2+}$. Possible candidates for $\mathrm{Mg}^{2+}$ ligands provided by proteins include aspartate and glutamate side chains, which have been shown to function in $\mathrm{Mg}^{2+}$ coordination at the $3^{\prime} \rightarrow 5^{\prime}$ exonuclease active site of the DNA polymerase I Klenow fragment (Beese and Steitz 1991). An indirect effect could be structural alteration upon CBP2 protein binding that puts an RNA functional group into the correct geometry to act as a $\mathrm{Mg}^{2+}$ ligand. This model, invoking either a direct or an indirect effect of CBP2 protein on $\mathrm{Mg}^{2+}$ binding, and the standard model involving $\mathrm{Mg}^{2+}$ or protein in structural stabilization are not mutually exclusive. It is possible that the protein acts both to stabilize the correct folded structure of the RNA and to strengthen a specific $\mathrm{Mg}^{2+}$ site at or near the active site.

\section{Materials and methods}

\section{Plasmid construction}

The plasmid pBS + /bI5 contains the entire insert from the previously described SP65/bI2 plasmid (Gampel and Tzagoloff 1987) ligated into the polylinker of the vector pBS + (Stratagene). The terminal intron of the yeast mitochondrial cytochrome $b$ gene is referred to in the literature as either bI 2 or bI5 depending on the number of cytochrome $b$ introns in the strain used in the study (Gampel et al. 1989). Thus, bI2 and bI5 describe the same intron. pBS +/bI5 was linearized with $\mathrm{XbaI}$ to generate a template for $\mathrm{T} 7$ transcription. Wild-type bI5 RNA contains, in order from 5 ' to 3 ', 26-nucleotide pBS + polylinker, 104-nucleotide bI4, 50-nucleotide exon 5, 738-nucleotide bI5, 42-nucleotide exon 6, and 6-nucleotide pBS + polylinker. Earlier studies describe the bI5 intervening sequence (IVS) as $733 \mathrm{nu}-$ cleotides in length (Nobrega and Tzagoloff 1980). Incorporation of sequence revisions (Bonjardim and Nobrega 1984) in the L8 region reveals the correct length of the bI5 IVS to be 738 nucleotides. pTDi was constructed by ligation of the 1.6-kb HindIIEcoRV fragment of pUC9-Td (Chu et al. 1984) into the pT7-2 vector (U.S. Biochemical) and linearized with EcoRI. $t d$ RNA contains a 9-nucleotide polylinker, 392-nucleotide $5^{\prime}$ exon, 1016-nucleotide $t d$ intron, 202-nucleotide $3^{\prime}$ exon, and 28-nucleotide polylinker. pNi contains the 879-bp BgIII-HpaI frag- 
ment of pJSS10 (Gott et al. 1988) ligated into the pT7-1 vector (U.S. Biochemical). This plasmid was linearized with HindIII to generate a template with the $n r d B$ intron. $n r d B$ RNA contains a 28-nucleotide polylinker, 79-nucleotide exon 1, 598-nucleotide $\operatorname{nrdB}$ intron, 200-nucleotide exon 2, and 17-nucleotide polylinker. The phagemid pTZ18U/bI5 used for site-directed mutagenesis contains the mitochondrial DNA insert of $\mathrm{pBS}+/ \mathrm{bI} 5$ subcloned into the phagemid vector pTZ18U (Mead et al. 1986).

\section{Preparation of RNA}

Transcription reactions for preparation of unlabeled RNA contained $40 \mathrm{~mm}$ Tris (pH 7.5), $6 \mathrm{~mm} \mathrm{MgCl}_{2}, 5 \mathrm{~mm}$ DTT, $1 \mathrm{~mm}$ spermidine, $0.5 \mathrm{~mm}$ each ribonucleotide, $0.2 \mu \mathrm{g} / \mathrm{ml}$ of linear template, and 2000 units of T7 RNA polymerase per microgram of template. T7 polymerase was isolated from Escherichia coli strain BL21 containing plasmid pAR1219 (Davanloo et al. 1984). Preparation of uniformly labeled RNA was the same except ATP was at $10 \mu \mathrm{M}$ and $\left[\alpha^{-}{ }^{32} \mathrm{P}\right] \mathrm{ATP}$ was included at a final $\mathrm{sp}$. ac. of $0.2 \mathrm{Ci} / \mu \mathrm{mole}$. RNA was isolated from $4 \%$ polyacrylamide $/ 8 \mathrm{M}$ urea gels by soaking gel slices in $10 \mathrm{~mm}$ Tris (pH 7.5), $250 \mathrm{~mm} \mathrm{NaCl}$, and $1 \mathrm{~mm}$ EDTA, followed by ethanol precipitation.

\section{Chemical modification with CMCT}

Reactions under native conditions were done with $0.1 \mu \mathrm{M}$ RNA in $50 \mathrm{~mm}$ potassium borate ( $\mathrm{pH} 8), 5 \mathrm{mM} \mathrm{MgCl}_{2}, 50 \mathrm{mM} \mathrm{KCl}$, and $5 \mathrm{mg} / \mathrm{ml}$ of CMCT (Sigma) at $37^{\circ} \mathrm{C}$ for $1-30 \mathrm{~min}$. Denaturing conditions were with $0.1 \mu \mathrm{M}$ RNA in $50 \mathrm{~mm}$ potassium borate (pH 8), $1 \mathrm{mM}$ EDTA, $50 \mathrm{~mm} \mathrm{KCl}$, and $0.4 \mathrm{mg} / \mathrm{ml}$ of CMCT at $95^{\circ} \mathrm{C}$ for $0.5-10 \mathrm{~min}$. Reactions were stopped by the addition of $25 \mu \mathrm{l}$ of $1.5 \mathrm{M} \mathrm{NaOAc}, 5 \mu \mathrm{l}$ of yeast tRNA $(0.6 \mathrm{mg} / \mathrm{ml})$, and 375 $\mu l$ of ethanol on ice. Samples were transferred to dry ice for 3 min, centrifuged for $5 \mathrm{~min}$, rinsed with $70 \%$ ethanol, dried, and dissolved in $10 \mathrm{~mm}$ Tris $(\mathrm{pH} 8.0)$ and $0.1 \mathrm{~mm}$ EDTA. Sites of modification were revealed by reverse transcription from the synthetic oligonucleotide primers IP257-20, IP337-21, IP388-24, IP437-20, IP499-32, and IP697-21. The 3' nucleotide of IP257-20 is complementary to nucleotide 257 of bI5 (bI5 numbering system with the first nucleotide of the IVS as it exists in the precursor as number 1), and the primer contains a total of $20 \mathrm{nu}$ cleotides. All primers are named according to the same rationale. Each $5^{\prime}-{ }^{32} \mathrm{P}$-labeled primer ( 1 pmole) was annealed to 0.5 pmole of modified RNA in $25 \mathrm{~mm}$ Tris (pH 8.3), $30 \mathrm{~mm} \mathrm{NaCl}$, and $5 \mathrm{~mm}$ DTT by heating at $95^{\circ} \mathrm{C}$ for $3 \mathrm{~min}$ followed by quick cooling on ice. Primer extension was done at $37^{\circ} \mathrm{C}$ in annealing buffer plus $15 \mathrm{~mm} \mathrm{MgOAc,} 0.25 \mathrm{~mm}$ each $\mathrm{dNTP}$, and $0.2 \mathrm{U} / \mu \mathrm{l}$ of AMV reverse transcriptase (Life Sciences). Reaction products were separated on $8 \%$ polyacrylamide $/ 8 \mathrm{M}$ urea gels.

\section{bI5 variants}

Site-directed mutagenesis of pTZ18U/bI5 was carried out by the method of Kunkel (1985). For $\Delta \mathrm{L} 1$ and $\Delta \mathrm{L} 1-10$, nucleotides 3-223 and 5-221, respectively, were deleted and replaced with a $B a m H I$ restriction site. $\Delta \mathrm{Ll}-\mathrm{B}$ contains the BamHI-EcoRI fragment of $\Delta \mathrm{L} 1$ ligated to the $\mathrm{pBS}+$ vector. In $\Delta \mathrm{L} 8, \mathrm{~L} 8$ is replaced by a $B g$ III restriction site. In $\Delta \mathrm{L} 6$, nucleotides $355-436$ are removed and replaced with a $S m a I$ restriction site. $\Delta \mathrm{L} 8 / B g / I I$ is the transcript from the $\Delta \mathrm{L} 8$ variant plasmid linearized at the BglII site. $\triangle$ P7.1 is described in Figure 2B, and the replacement variant RP5td is shown in Figure 4. The G : $U$ mutant (C311U) was made in the wild-type pTZ18U/bI5 background. The A : C mutant was cloned from the mitochondrial DNA of the in vivoisolated mutant M6-200 (P. Perlman, unpubl.). In addition to the G264A change at the $G$ site, this variant has a second base change in the core, G427U. The A : U compensatory mutant (G264A: C311U) was constructed in the M6-200 background and therefore also contains the G427U change. Mutant sequences were verified by sequencing with reverse transcriptase from the primers described above.

\section{Kinetic analysis}

For the purposes of a kinetic analysis of binding, the CBP2 protein was treated as the enzyme, and the RNA was treated as the substrate of the reaction. The analysis was done under subsaturating conditions for both enzyme and substrate, where the initial rate of protein-dependent splicing is a linear function of either protein or RNA concentration. This was demonstrated for the ranges $0.1-10 \mathrm{nM}$ RNA and 4-30 nM protein. The $K_{\mathrm{m}}$ value was estimated to be $>200 \mathrm{nM}$ because plots of splicing rate versus RNA concentration deviated from linearity above 200 nM RNA. The exact value has not been determined because of small quantities of purified protein. The inhibition constant $K_{\mathrm{i}}$ was determined by two methods. For method A, the concentration of bI5 RNA was varied at fixed inhibitor RNA concentration $(I)$, and the splicing rates $(v)$ were plotted as a function of [bI5 RNA] (see Fig. 3B). For method B, [bI5 RNA] was fixed while $I$ was varied, and $v$ was plotted as a function of $I$. For both methods, precursor RNA was incubated in $20 \mathrm{mM}$ Tris (pH 7.5), $20 \mathrm{mM}\left(\mathrm{NH}_{4}\right)_{2} \mathrm{SO}_{4}, 5 \mathrm{mM} \mathrm{MgCl}_{2}, 5 \mathrm{mM} \mathrm{CaCl}_{2}, 2 \mathrm{mM}$ spermidine, $5 \mathrm{~mm}$ DTT, $60 \mu \mathrm{g} / \mathrm{ml}$ of yeast tRNA, $0.5 \mathrm{~mm}$ GTP, and $15 \mathrm{~mm}$ $\mathrm{CBP} 2$ protein at $37^{\circ} \mathrm{C}$. For method $\mathrm{A}$, splicing assays contained 0.1-10 nM uniformly labeled bI5 RNA and 10,50,200, or $900 \mathrm{nM}$ [G264A only) inhibitor RNA. Each determination of $\mathrm{V}_{\max } / K_{\mathrm{m}}$ included data from a minimum of four bI5 concentrations. Aliquots were removed into urea/dye mix at 1 - to 10 -min time points, and reaction products were separated on $10 \%$ polyacrylamide $/ 8 \mathrm{M}$ urea gels. Counts in each of the two product bands, ligated exons (LE) and $5^{\prime}$ exon $\left(5^{\prime} \mathrm{E}\right)$, and in the upper band containing precursor, IVS $-3^{\prime}$ exon, and IVS were quantitated by radioanalytical imaging (Molecular Dynamics Phosphorimager) of dried gels. Counts in the upper band, LE, and $5^{\prime} \mathrm{E}$ were converted to molar amounts according to the number of adenine nucleotides (because the RNA was A-labeled) in each: Counts in the upper band were divided by 409 moles of A/mole of RNA (the value characteristic of the precursor RNA); counts in LE were divided by 78 moles of $\mathrm{A} /$ mole of RNA; and counts in $5^{\prime} \mathrm{E}$ were divided by 65 moles of $\mathrm{A} / \mathrm{mole}$ of RNA. These corrected counts were then used to calculate percent product $=\left(\mathrm{LE}+5^{\prime}\right.$ E) $\times 100 /\left(\right.$ upper band $+\mathrm{LE}+5^{\prime}$ E). The approximation that the upper band contained only precursor RNA does not lead to significant error, because the reaction proceeded to $<5 \%$ completion. Splicing rates were determined from direct plots of percent product versus time. $\mathrm{V}_{\max } / K_{\mathrm{m}}$ and $\mathrm{V}_{\max } / K_{\mathrm{m}}$ (app) were determined from plots of splicing rate versus RNA concentration. This method of $K_{\mathrm{i}}$ calculation does not require determinations of $\mathrm{V}_{\max }$ or $K_{\mathrm{m}}$ but, rather, relies on the ratio. For method $\mathrm{B}$, reactions contained $0.5 \mathrm{nM}$ uniformly labeled bI5 and unlabeled inhibitor at $0.6-200 \mathrm{nM}$ in fivefold increments. Products were separated on $4 \%$ polyacrylamide $/ 8 \mathrm{M}$ urea gels. At low concentrations of $S$ relative to $K_{\mathrm{m}}, \mathrm{v} / S$ is equal to $\mathrm{V}_{\max } / K_{\mathrm{m}}$. In the presence of inhibitor $(I), v_{\mathrm{l}} / \mathrm{S}$ is equal to $\mathrm{V}_{\max } / K_{\mathrm{m}}\left(1+I / K_{\mathrm{i}}\right)$. Thus, the reaction rate in the presence of inhibitor, $v_{\mathrm{l}}$, is equal to $v / 2$ (half the rate in the absence of inhibitor) when the factor $\left(1+I / K_{i}\right)$ is equal to 2 . This is true when the concentration of inhibitor is equal to $K_{\mathrm{i}}$. The concentration of inhibitor that re- 
duced splicing by $50 \%$ was estimated from autoradiograms to generate values for $K_{\mathrm{i}}$ by method B.

\section{Splicing assays for G-site variants}

Reactions were done under the same conditions as for the $K_{\mathrm{i}}$ determinations, with $0.5 \mathrm{nM}$ uniformly labeled bI5 except for the variations in $\mathrm{Mg}^{2+}$ concentration, presence or absence of protein, and added cofactor as indicated. Cofactor concentrations were $2.5 \mathrm{~mm} \mathrm{G}$, 2-AP (Sigma), or 6-Cl-2-AP (Aldrich; Robins and Uznanaski 1981). Quantitation for the experiment with RP5td was done by AMBIS radioanalytic scanning of dried polyacrylamide gels. The identity of the reaction products has been described previously (Gampel and Tzagoloff 1987; Partono and Lewin 1988).

\section{Self-splicing assays}

Self-splicing activities reported in Table 1 were determined under conditions identical to those for protein-dependent splicing except at $50 \mathrm{mM} \mathrm{Mg}{ }^{2+}$. Assays were done with measurements at one or two time points between 10 and $60 \mathrm{~min}$.

\section{Purification of CBP2 protein}

The purification procedure is modified from that described previously (Gampel et al. 1989). Mitochondria were prepared from $\alpha$-W303-1B cells (R. Rothstein) grown in YPG ( $2 \%$ galactose, $2 \%$ Bacto-peptone, $1 \%$ yeast extract) to late log phase. Mitochondria were harvested from 9 liters of cells (average yield of 140 grams wet weight), resuspended in $15 \mathrm{ml}$ of $20 \mathrm{~mm}$ Tris (pH 7.5), and disrupted by sonication (Heat Systems-Ultrasonics sonicator $\mathrm{W}-225$ ) at the maximum output with a microtip, three rounds of $10 \mathrm{sec}$ each. All procedures were carried out on ice or at $4^{\circ} \mathrm{C}$. Disrupted mitochondria were centrifuged in a Beckman TL-100 centrifuge, TLA-100.3 rotor, at $80,000 \mathrm{rpm}$ for $30 \mathrm{~min}$. Streptomycin sulfate was added to the supernatant $(0.1$ volume of $10 \%$ ) and incubated on ice for $10 \mathrm{~min}$. Precipitate was collected by centrifugation in 15-ml Corex tubes at 12,000 rpm for $30 \mathrm{~min}$ in JS13.1 rotor and washed once in $12 \mathrm{ml}$ of $50 \mathrm{~mm}$ Tris (pH 7.5) and $1 \mathrm{~mm}$ EDTA. Protein was extracted from the pellet by homogenizing gently in $6 \mathrm{ml}$ of $50 \mathrm{mM}$ Tris (pH 7.5), $1 \mathrm{~mm}$ EDTA, and $1 \mathrm{M} \mathrm{NaCl}$, followed by centrifugation as above. Two ammonium sulfate precipitations were done on the $1 \mathrm{M} \mathrm{NaCl}$ extract $(0-25 \%$ and $25-50 \%)$, collecting the precipitate by centrifugation at $80,000 \mathrm{rpm}$ for $30 \mathrm{~min}$ in the TLA- 100.3 rotor. The $25-50 \%$ ammonium sulfate pellet was dissolved in $1 \mathrm{ml}$ of column buffer [CB: $10 \mathrm{~mm}$ Tris (pH 7.5), $1 \mathrm{~mm}$ EDTA, $0.15 \mathrm{M} \mathrm{NaCl}$ ] and loaded onto a 4-ml DNA-cellulose column (denatured DNA, Pharmacia) by gravity filtration at $4 \mathrm{ml} / \mathrm{min}$. The column was rinsed with $8 \mathrm{ml}$ of $\mathrm{CB}$ and eluted stepwise with $4 \mathrm{ml}$ of $\mathrm{CB}$ plus $0.3 \mathrm{M} \mathrm{NaCl}, \mathrm{CB}$ plus $0.6 \mathrm{M} \mathrm{NaCl}$, and $\mathrm{CB}$ plus $2 \mathrm{M} \mathrm{NaCl}$. One-milliliter fractions were collected and dialyzed overnight into $10 \mathrm{~mm}$ Tris (pH 7.5), $0.1 \mathrm{~mm}$ EDTA, and $60 \%$ glycerol. $\beta$-Mercaptoethanol and phenylmethylsulfonyl fluoride were added to $250-\mu$ l dialyzed fractions to final concentrations of 10 $\mathrm{mM}$ and $0.1 \mathrm{mM}$, respectively. The last $2 \mathrm{ml}$ from the $0.6 \mathrm{M} \mathrm{NaCl}$ eluate and the first $1 \mathrm{ml}$ from the $2.0 \mathrm{M} \mathrm{NaCl}$ eluate contained most of the activity $1>90 \%$ with the remainder in the flowthrough fraction) in equal amounts. These three fractions were pooled and used in the protein-dependent splicing assays. A protein concentration of $15 \mathrm{nM}$ was estimated by density on a silver-stained gel compared with a BSA standard, with the assumption that silver staining of the $\mathrm{CBP} 2$ protein and that of the standard are comparable. Because all of the protein might not be active, $15 \mathrm{~nm}$ represents an upper limit for the concentration of active protein.

\section{Acknowledgments}

We thank Jennifer Davila-Aponte for construction of the phagemid $\mathrm{pTZ1} 18 \mathrm{U} / \mathrm{bI} 5$ and the $\Delta \mathrm{L} 1, \Delta \mathrm{L} 1-10$, and $\Delta \mathrm{L} 8$ variants. We also thank Cheryl Grosshans and Anne Ritter for oligodeoxyribonucleotide synthesis, Martha Fedor for helpful discussions, and Art Zaug for assistance in the early attempts at direct mapping. We are grateful to the W.M. Keck Foundation for their generous support of RNA science on the Boulder campus.

The publication costs of this article were defrayed in part by payment of page charges. This article must therefore be hereby marked "advertisement" in accordance with 18 USC section 1734 solely to indicate this fact.

\section{References}

Akins, R.A. and A.M. Lambowitz. 1987. A protein required for splicing group I introns in Neurospora mitochondria is mitochondrial tyrosyl-tRNA synthetase or a derivative thereof. Cell 50: 331-345.

Beese, L.S. and T.A. Steitz. 1991. Structural basis for the $3^{\prime}-5^{\prime}$ exonuclease activity of Escherichia coli DNA polymerase I: A two metal ion mechanism. EMBO I. 10: 25-33.

Bonjardim, C.A. and F.G. Nobrega. 1984. Revision of the nucleotides at the last intron of the mitochondrial apocytochrome $b$ gene of Saccharomyces cerevisiae. Braz. J. Med. Biol. Res. 17: $17-20$.

Burke, J.M., K.D. Irvine, K.J. Kaneko, B.J. Kerker, A.B. Oettgen, W.M. Tierney, C.L. Williamson, A.J. Zaug, and T.R. Cech. 1986. Role of conserved sequence elements $9 \mathrm{~L}$ and 2 in selfsplicing of the Tetrahymena ribosomal RNA precursor. Cell 45: 167-176.

Burke, J.M., M. Belfort, T.R. Cech, R.W. Davies, R.J. Schweyen, D.A. Shub, J.W. Szostak, and H.F. Tabak. 1987. Structural conventions for group I introns. Nucleic Acids Res. 15: 7217-7221.

Cech, T.R. 1988. Conserved sequences and structures of group I introns: Building an active site for RNA catalysis-A review. Gene 73: 259-271.

- 1990. Self-splicing of group I introns. Annu. Rev. Biochem. 59: 543-568.

Chu, F.K., G.F. Maley, F. Maley, and M. Belfort. 1984. Intervening sequence in the thymidylate synthase gene of bacteriophage T4. Proc. Nat1. Acad. Sci. 81: 3049-3053.

Couture, S., A.D. Ellington, A.S. Gerber, J.M. Cherry, J.A. Doudna, R. Green, M. Hanna, U. Pace, J. Rajagopal, and J.W. Szostak. 1990. Mutational analysis of conserved nucleotides in a self-splicing group I intron. J. Mol. Biol. 215: 345-358.

Davanloo, P., A.H. Rosenberg, J.J. Dunn, and F.W. Studier. 1984. Cloning and expression of the gene for bacteriophage T7 RNA polymerase. Proc. Natl. Acad. Sci. 81: 2035-2039.

Davies, R.W., R.B. Waring, J.A. Ray, T.A. Brown, and C. Scazzocchio. 1982. Making ends meet: A model for RNA splicing in fungal mitochondria. Nature 300: 719-724.

Ehresmann, C., F. Baudin, M. Mougel, P. Romby, J.-P. Ebel, and B. Ehresmann. 1987. Probing the structure of RNAs in solution. Nucleic Acids Res. 15: 9109-9128.

Gampel, A. and A. Tzagoloff. 1987. In vitro splicing of the terminal intervening sequence of Saccharomyces cerevisiae cytochrome $b$ pre-mRNA. Mol. Cell. Biol. 7: 2545-2551.

Gampel, A., M. Nishikimi, and A. Tzagoloff. 1989. CBP2 protein promotes in vitro excision of a yeast mitochondrial group I intron. Mol. Cell. Biol. 9: 5424-5433. 
Gott, J.M., A. Zeeh, D. Bell-Pederson, K. Ehrenman, M. Belfort, and D.A. Shub. 1988. Genes within genes: Independent expression of phage $\mathrm{T} 4$ intron open reading frames and the genes in which they reside. Genes \& Dev. 2: 1791-1799.

Guo, Q., R.A. Akins, G. Garriga, and A.M. Lambowitz. 1991. Structural analysis of the Neurospora mitochondrial large rRNA intron construction of a mini-intron that shows protein-dependent splicing. I. Biol. Chem. 266: 1809-1819.

Hill, J., P. McGraw, and A. Tzagoloff. 1985. A mutation in yeast mitochondrial DNA results in a precise excision of the terminal intron of the cytochrome $b$ gene. J. Biol. Chem. 260: 3235-3238.

Inoue, T. and T.R. Cech. 1985. Secondary structure of the circular form of the Tetrahymena rRNA intervening sequence: A technique for RNA structure analysis using chemical probes and reverse transcriptase. Proc. Natl. Acad. Sci. 82: 648-652.

Jaeger, J.A., M. Zuker, and D.H. Turner. 1990. Melting and chemical modification of a cyclized self-splicing group I intron: Similarity of structures in $1 \mathrm{M} \mathrm{Na}^{+}$, in $10 \mathrm{mM} \mathrm{Mg}^{2+}$, and in the presence of substrate. Biochemistry 29: 1014710158.

Kunkel, T.A. 1985. Rapid and efficient site-specific mutagenesis without phenotypic selection. Proc. Natl. Acad. Sci. 82: 488-492.

Lazowska, J., M. Claisse, A. Gargouri, Z. Kotylak, A. Spyridakis, and P.P. Slonimski. 1989. Protein encoded by the third intron of cytochrome $b$ gene in Saccharomyces cerevisiae is a messenger RNA maturase: Analysis of mitochondrial mutant, RNA transcripts, proteins and evolutionary relationships. J. Mol. Biol. 205: 275-290.

Majumder, A.L., R.A. Akins, J.G. Wilkenson, R.L. Kelley, A.J. Snook, and A.M. Lambowitz. 1989. Involvement of tyrosyltRNA synthetase in splicing of group I introns in Neurospora crassa mitochondria. Biochemical and immunological analysis of splicing activity. Mol. Cell. Biol. 9: 2089-2104.

McGraw, P. and A. Tzagoloff. 1983. Assembly of the mitochondrial membrane system. Characterization of a yeast nuclear gene involved in the processing of the cytochrome $b$ premRNA. J. Biol. Chem. 258: 9459-9468.

Mead, D.A., E. Szczesna-Skorupa, and B. Kemper. 1986. Singlestranded DNA "blue" $\mathrm{T} 7$ promoter plasmids: A versatile tandem promoter system for cloning and protein engineering. Protein Eng. 1: 67-74.

Michel, F. and E. Westhof. 1990. Modelling of the three-dimensional architecture of group I catalytic introns based on comparative sequence analysis. J. Mol. Biol. 216: 585-610.

Michel, F., A. Jacquier, and B. Dujon. 1982. Comparison of fungal mitochondrial introns reveals extensive homologies in RNA secondary structure. Biochimie 64: 867-881.

Michel, F., M. Hanna, R. Green, D.P. Bartel, and J.W. Szostak. 1989. The guanosine binding site of the Tetrahymena ribozyme. Nature 342: 391-395.

Moazed, D., S. Stern, and H.F. Holler. 1986. Rapid chemical probing of conformation in $16 \mathrm{~S}$ ribosomal RNA and $30 \mathrm{~S} \mathrm{ri-}$ bosomal subunits using primer extension. J. Mol. Biol. 187: 399-416.

Nobrega, F.G. and A. Tzagoloff. 1980. Assembly of the mitochondrial membrane system. DNA sequence and organization of the cytochrome $b$ gene in Saccharomyces cerevisiae D273-1OB. J. Biol. Chem. 255: 9828-9837.

Partono, S. and A. Lewin. 1988. Autocatalytic activities of intron 5 of the $c o b$ gene of yeast mitochondria. Mol. Cell. Biol. 18: 2562-2571.

Perlman, P.S. and R.A. Butow. 1989. Mobile introns and intronencoded proteins. Science 246: 1106-1109.
Robins, M.J. and B. Uznanski. 1981. Nucleic acid related compounds. 33 . Conversion of adenosine and guanosine to 2,6dichloro, 2-amino-6-chloro, and derived purine nucleosides. Can. J. Chem. 59: 2601-2607.

Sampson, J.R., A.B. DiRenzo, L.S. Behlen, and O.C. Uhlenbeck. 1990. Role of the tertiary nucleotides in the interaction of yeast phenylalanyl tRNA with its cognate synthetase. Biochemistry 29: 2523-2532.

Shub, D.A., J.M. Gott, M.-Q. Xu, B.F. Lang, F. Michel, J. Tomaschewski, and M. Belfort. 1988. Structural conservation among three homologous introns of bacteriophage T4 and the group I introns of eukaryotes. Proc. Natl. Acad. Sci. 85: 1151-1155.

Zaug, A.J., C.A. Grosshans, and T.R. Cech. 1988. Sequencespecific endoribonuclease activity of the Tetrahymena ribozyme: Enhanced cleavage of certain oligonucleotide substrates that form mismatched ribozyme-substrate complexes. Biochemistry 27: 8924-8931. 


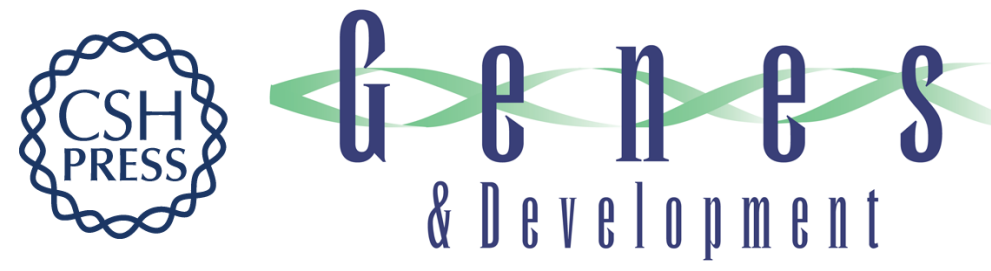

\section{Binding of the CBP2 protein to a yeast mitochondrial group I intron requires the catalytic core of the RNA.}

A Gampel and T R Cech

Genes Dev. 1991, 5:

Access the most recent version at doi:10.1101/gad.5.10.1870

References This article cites 35 articles, 13 of which can be accessed free at:

http://genesdev.cshlp.org/content/5/10/1870.full.html\#ref-list-1

License

Email Alerting

Service

Receive free email alerts when new articles cite this article - sign up in the box at the top right corner of the article or click here.

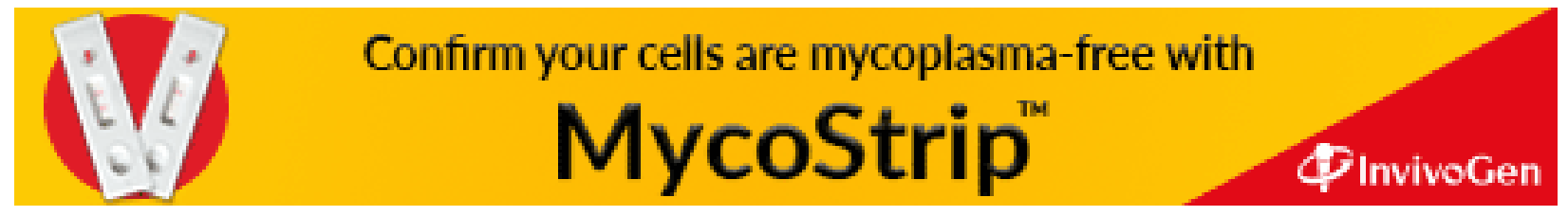

